\title{
ANALISA TINGKAT PENCEMARAN AIR BAWAH TANAH DENGAN METODE GEOLISTRIK KONFIGURASI SCHLUMBERGER DI KECAMATAN TAMPAN KOTA PEKANBARU
}

\author{
Juandi $\mathbf{M}^{1, *}$, Usman Malik ${ }^{1}$, Melki Leonardo ${ }^{2, *}$ \\ ${ }^{1}$ Dosen Jurusan Fisika \\ ${ }^{2}$ Mahasiswa Program Studi S1 Fisika \\ Fakultas Matematika dan Ilmu Pengetahuan Alam, \\ Universitas Riau Kampus Bina Widya \\ J1. Prof. Muchtar Luthfi Pekanbaru, 28293, Indonesia \\ *E-mail: juandi@ lecturer.unri.ac.id \\ Melkyleonardo176@gmail.com
}

\begin{abstract}
The research analyzing ground water contamination based on Geo-electrical methods near 2 point, that is in Cipta Karya street (without waste pile) and Srikandi street (with waste pile), Kecamatan Tampan Riau. Data was processed using Software Progress, with the results of processing in the form of depth, thickness and number of layers and the resistivity value. Has been done the results obtained showed that the resistivity value on Cipta Karya road without garbage pile was 57.10-4955.00 Ohm.m at depth 0,00-346,00 Meter and on Srikandi street with garbage pile was 68.90-4008.00 Ohm.m at depth 0,00-367,00 Meter. Geo-electrical data measurements in Cipta Karya and Srikandi there are 5 layers of soil, that is cover layer, clay loam layer, alluvium layer, sand layer and bedrock layer. Based on the above resistivity values and depth, all points considered un polluted by leachet because the resistivity value is far above 10 Ohm.m (fresh water). Resistivity values indicate that the leachet does not seep into the soil and spread to swamps which are right next to the garbage pile (Srikandi road).
\end{abstract}

Keywords: contamination, ground water, geo-electrical methods.

\begin{abstract}
ABSTRAK
Penelitian ini menganalisa pencemaran air tanah berdasarkan metode geolistrik yang didekatkan pada 2 titik, yaitu pada jalan Cipta Karya (tanpa timbunan sampah) dan Srikandi (adanya timbunan sampah), kecamatan Tampan. Data diolah menggunakan Software Progress dengan hasil pengolahan berupa kedalaman, ketebalan dan jumlah lapisan serta nilai resistivitas. Hasil yang diperoleh adalah nilai resistivitas pada jalan Cipta Karya tanpa timbunan sampah 57,10-4955,00 Ohm.m pada kedalaman 0,00-346,00 m dan jalan Srikandi adanya timbunan sampah 68,90-4008,00 Ohm.m. pada kedalaman 0,00-367,00 m. Pengukuran data geolistrik di Cipta Karya dan Srikandi terdapat 5 lapisan tanah, yaitu lapisan penutup, lapisan lempung pasiran, lapisan alluvium, lapisan pasir dan lapisan bedrock. Berdasarkan nilai resistivitas dan kedalaman diatas serta jumlah lapisan yang diperoleh, sетиa titik dianggap tidak tercemar oleh air lindi karena nilai resistivitasnya jauh diatas 10 ohm.m (air tawar). Nilai resistivitas menunjukkan bahwa air lindi tidak meresap kedalam tanah dan menyebar kearah rawa-rawa yang berada tepat di samping timbunan sampah (jalan Srikandi).
\end{abstract}

Kata Kunci: Pencemaran, air tanah, metode geolistrik.

\section{PENDAHULUAN}

Aktivitas manusia dalam memanfaatkan alam selalu meninggalkan sisa yang dianggap sudah tidak berguna lagi sehingga diperlakukan sebagai barang buangan yaitu sampah. Sampah merupakan polutan umum yang dapat menyebabkan turunnya nilai estetika lingkungan, membawa berbagai jenis penyakit, menurunkan sumber daya, menimbulkan polusi, menyumbat saluran air dan berbagai akibat negatif lainnya, sehingga manusia menyingkirkan sampah sejauh mungkin dari aktivitas manusia yang biasa disebut Tempat Pembuangan Akhir (TPA) sampah [1].

Kebutuhan manusia akan air berkualitas tinggi semakin pesat dari tahun ke tahun diiringi dengan kemajuan teknologi. Dan air tanah dipandang sebagai salah satu sumber 
air bersih yang sangat potensial untuk digunakan dalam memenuhi kebutuhan tersebut. Air tanah adalah air yang terdapat di dalam lapisan tanah atau bebatuan di bawah permukaan tanah yang berasal dari air hujan ataupun sumber lainnya yang masuk ke dalam tanah dengan bantuan gravitasi. Di sisi lain kualitas air tanah tersebut semakin menurun karena meningkatnya pencemaran air. Air tanah ini dapat dieksploitasi secara terus menerus namun harus tetap dijaga keseimbangan dan pelestariannya.

Pencemaran air tanah yang disebabkan oleh limbah merupakan salah satu masalah yang dihadapi oleh masyarakat Kecamatan Tampan, baik limbah industri maupun limbah rumah tangga. Umumnya limbah yang dibuang ke lingkungan akan mempengaruhi kualitas air tanah dimana limbah dibuang [2]. Apabila dilihat dari bahaya yang ditimbulkan limbah ini ada yang berbahaya dan ada yang tidak berbahaya. Pembuangan limbah yang berbahaya akan menjadi persoalan besar, apabila air yang dikonsumsi oleh manusia, hewan, dan organisme tercemar limbah yang mengandung senyawa berbahaya.

Metode yang banyak dipakai dalam studi pencemaran air bawah tanah adalah metode geolistrik. Metode ini melibatkan pengukuran potensial, arus dan medan elektromagnetik yang terjadi secara alamiah maupun akibat injeksi arus. Salah satu jenis metode geolistrik yaitu geolistrik tahanan jenis atau yang sering disebut metode resistivity [3].

\section{METODOLOGI PENELITIAN}

\section{Teknik pengambilan data}

Pengukuran dilaksanakan di kawasan Kecamatan Tampan Kota Pekanbaru dengan mengambil 2 titik sampel yakni 1 titik sampel berada di daerah yang ada timbunan sampahnya dan 1 titik sampel lainnya berada tanpa adanya timbunan sampah dengan menarik titik sampel sepanjang 300 meter. Teknik pengukuran didasarkan pada pengambilan data geolistrik Schlumberger. Alat dihubungkan pada elektrodaelektroda yang dipancangkan dengan meletakkan alat resistivitas di tengah-tengah pengaturan elektroda arus dan elektroda potensial seperti pada pengaturan elektroda schlumberger. Susunan elektroda schlumberger dalam pelaksanaan di lapangan adalah dengan mengatur jarak antara masing-masing elektroda, dimana elektroda potensial MN selalu ditempatkan di antara elektroda arus $\mathrm{AB}$ demikian seterusnya sampai titik pengukuran pengambilan data pada line A-B berkisar 300 meter.

Langkah-langkah pengambilan data adalah : pertama observasi lapangan dengan mensurvei daerah mana yang ada timbunan sampah dan tanpa timbunan sampah di Kecamatan Tampan Kota Pekanbaru sebagai titik sampelnya. Selanjutnya membentangkan meteran sebagai tempat pengecekan titik-titik tancapan elektroda sepanjang 300 meter, penancapan elektroda, selanjutnya penghubungan dengan terminal arus dan potensial, kemudian data boleh diambil dengan cara menghidupkan Resistivytimeter sebagai pengatur arus input dan arus output.

Besarnya arus dan tegangan untuk setiap perubahan jarak elektroda arus dan elektroda potensial dicatat untuk berbagai pengukuran. Hasil yang diperoleh diproses dengan komputer menggunakan program progress selanjutnya diinterpretasikan untuk memperoleh daerah mana yang anomali polutannya besar atau kecil dan arah pergerakan air lindi di wilayah Kecamatan Tampan Kota Pekanbaru.

\section{Pengolahan data}

Hasil yang didapatkan dari lokasi penelitian berupa data resistivitas yang diolah dengan menggunakan software progress. Langkah-langkah penggunaan software progress untuk memproses data geolistrik adalah sebagai berikut :

1. Data hasil pengukuran berupa nilai elektroda arus, nilai elektroda potensial, kuat arus dan tegangan diolah dengan program Excel untuk menentukan faktor geometri dan nilai resistivitasnya. 
2. Data yang diolah di program Excel kemudian diinput ke software Progres.

3. Data yang telah diinput kemudian menghasilkan pengolahan data berupa grafik dengan nilai-nilai resistivitas pada setiap lapisan beserta dengan nilai-nilai kedalamannya.

4. Dari grafik yang diperoleh dapat dibuat model resistivitasnya dengan melihat litologinya yang sesuai dengan nilai-nilai resistivitas serta kedalamannya.

5. Pengolahan data selanjutnya dengan menggunakan Software progress.

\section{HASIL DAN PEMBAHASAN}

\section{Hasil pengolahan data nilai resistivitas}

Data yang diperoleh dari pengukuran di lapangan dengan menggunakan alat geolistrik konfigurasi Schlumberger terdiri dari parameter arus dan beda tegangan data tersebut kemudian dikonversikan menjadi resistivitas semu yang diperoleh dan hasilnya diolah dengan komputer menggunakan program progress. Hasil yang diperoleh dengan program progress ini merupakan harga tahanan jenis yang sebenarnya (true resistivity) dan mewakili nilai resistivitas berbedabeda dan menunjukkan arah pergerakan air lindi dan identifikasi adanya pencemaran pada sistem air bawah tanah [4]. Hasil pengolahan data ditunjukkan pada Gambar 1 berikut.

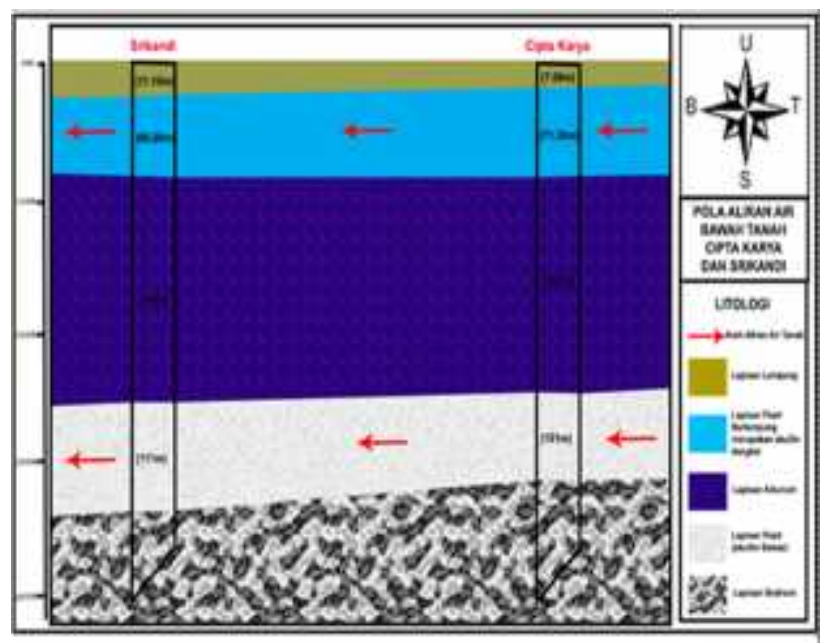

Gambar 1. Hasil pengolahan data geolistrik di Cipta Karya dan Srikandi.

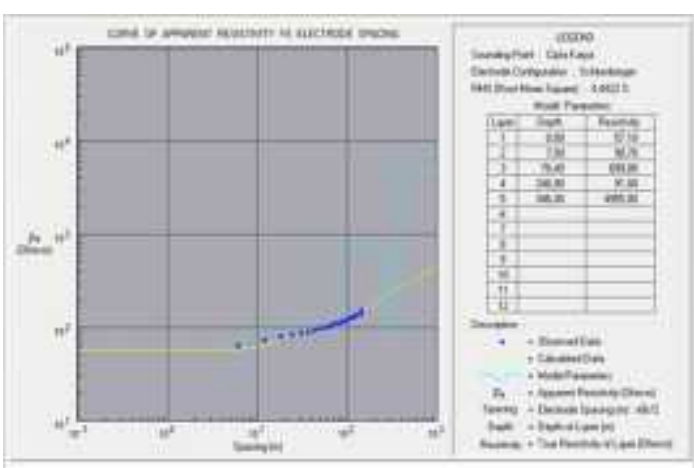

Gambar 2. Model dari litologi dengan nilai resitivitas setiap lapisan di daerah Cipta Karya.

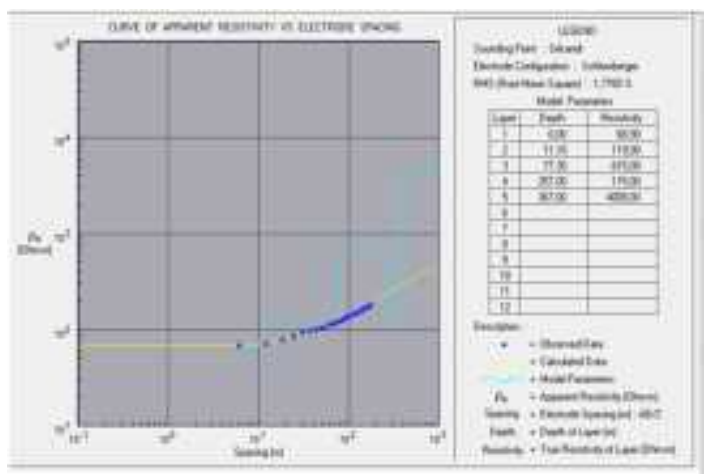

Gambar 3. Model dari litologi dengan nilai resitivitas setiap lapisan di daerah Srikandi.

\section{Analisa dan interprestasi nilai resistivitas}

Gambar 1 adalah hasil pengolahan data geolistrik di Cipta Karya dan Srikandi yang terdiri dari 5 lapisan tanah, yaitu pada lapisan pertama adalah lapisan tanah penutup, lapisan kedua adalah lapisan lempung pasiran, lapisan ketiga adalah lapisan alluvium, lapisan keempat adalah lapisan pasir dan lapisan kelima adalah lapisan bedrock. Kelima lapisan ini khususnya yang ada timbunan sampah yaitu pada Jalan Srikandi tidak tercemar oleh polutan air lindi karena air lindi tidak meresap sampai ke bawah lapisan tanah dan hanya menyebar secara horizontal ke arah rawa-rawa tepat berada di samping timbunan sampah. Arah sebarannya yaitu dari Cipta Karya ke Srikandi dan menuju ke arah rawa-rawa di samping timbunan sampah [5].

Lintasan titik 1 (pertama) pada koordinat Lintang Selatan $00^{\circ} 28^{\prime} 11.61$ ” dan koordinat 
Bujur Timur $101^{\circ} 22^{\prime} 41.84^{\prime \prime}$ terletak di jalan Cipta Karya dengan panjang lintasan 300 meter. Analisa data dengan menggunakan program progress memberikan gambaran lapisan tanah hingga kedalaman 346,00 m di lintasan titik pertama jalan Cipta Karya seperti terlihat pada Gambar 2. Hasil inversi menunjukkan pada lapisan pertama dengan resistivitas 57,10 ohm.m dengan kedalaman 0,00 meter diinterprestasikan sebagai lapisan Tanah Penutup. Lapisan kedua dengan resistivitas 98,70 ohm.m dengan kedalaman 7,09 meter diinterprestasikan sebagai lapisan Lempung Pasiran. Lapisan ketiga dengan resistivitas 699,00 ohm.m dengan kedalaman 78,40 meter diinterprestasikan sebagai lapisan Alluvium. Lapisan keempat dengan resistivitas 91,00 ohm.m dengan kedalaman 246,00 meter diinterprestasikan sebagai lapisan Pasir. Lapisan kelima dengan resistivitas 4955,00 ohm.m dengan kedalaman 346,00 meter diinterprestasikan sebagai lapisan Bedrock. Nilai resistivitas ini memiliki tingkat kesalahan (error) 4,4422\% [6].

Lintasan titik 2 (kedua) pada koordinat Lintang Selatan 0'29'49" dan koordinat Bujur Timur $101^{\circ} 23^{\prime} 48^{\prime \prime}$ terletak di jalan Srikandi dengan panjang lintasan 300 meter. Analisa data dengan menggunakan program progress memberikan gambaran lapisan tanah hingga kedalaman 367,00 $m$ di lintasan titik kedua jalan Srikandi seperti terlihat pada Gambar 3. Hasil inversi menunjukkan pada lapisan pertama dengan resistivitas 68,90 ohm.m dengan kedalaman 0,00 meter diinterprestasikan sebagai lapisan Tanah Penutup. Lapisan kedua dengan resistivitas 119,00 ohm.m dengan kedalaman 11,10 meter diinterprestasikan sebagai lapisan Lempung Pasiran. Lapisan ketiga dengan resistivitas 615,00 ohm.m dengan kedalaman 77,30 meter diinterprestasikan sebagai lapisan Alluvium. Lapisan keempat dengan resistivitas 115,00 ohm.m dengan kedalaman 257,00 meter diinterprestasikan sebagai lapisan Pasir. Lapisan kelima dengan resistivitas 4008,00 ohm.m dengan kedalaman 367,00 meter diinterprestasikan sebagai lapisan Bedrock. Nilai resistivitas ini memiliki tingkat kesalahan (error) $1,7765 \%$ [7].
Tabel 1. Hasil interpretasi pencemaran TPA di Srikandi.

\begin{tabular}{|c|c|c|c|c|}
\hline Lapisan & Litologi & $\begin{array}{c}\text { Kedabaman } \\
\text { (meter) }\end{array}$ & $\begin{array}{l}\text { Resintivitas } \\
\text { (ohm.m) }\end{array}$ & Keterangan \\
\hline$t$ & Tath penanup & 0,00 & 68,90 & Tifak tercesear \\
\hline II & Lempults pasiras & 11,10 & 119,00 & Tidaḱ terentas \\
\hline III & Alluvium & 77,30 & 615,00 & Tidak, tercental \\
\hline IV & Lapisas pair & 237,60 & 115,00 & Tdak teseenas \\
\hline V & Lupiasa bedrodk & 367,00 & 4008,00 & Fidak tereen=u \\
\hline
\end{tabular}

Tabel 2. Hasil interpretasi pencemaran di Cipta Karya.

\begin{tabular}{|c|c|c|c|c|}
\hline Lapisan & Litologi & $\begin{array}{c}\text { Kedalaman } \\
\text { (meter) }\end{array}$ & $\begin{array}{l}\text { Resistrintas } \\
\text { (ohm.m) }\end{array}$ & Keterangan \\
\hline 1 & Tamah pewtup & 0,00 & 57,10 & Tidak tacema \\
\hline II & Lenpung pasiran & 7,09 & 98,70 & Tidak tecems \\
\hline III & Alluviem & 78,40 & 699,00 & Tidak tercemn \\
\hline IV & Lapisan pasir & 246,00 & 91,00 & Tidak tecems \\
\hline V & Lapisan bedrock & 346,00 & 4953,00 & Tidak tercems \\
\hline
\end{tabular}

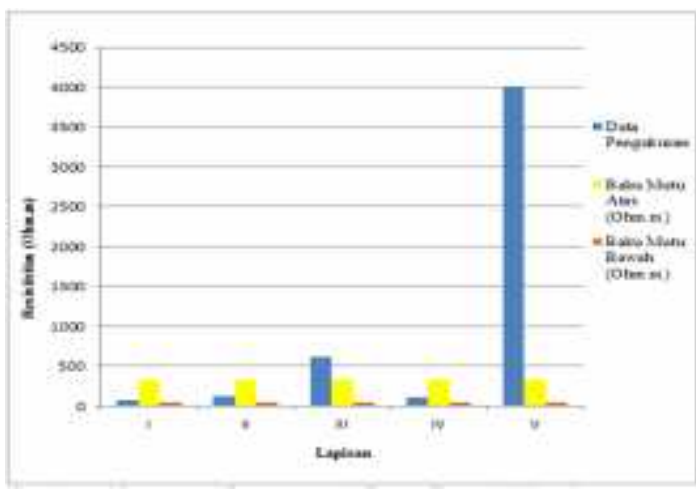

Gambar 4. Interpretasi pencemaran air bawah tanah di Srikandi.

Daerah Srikandi, berdasarkan diagram diatas menunjukkan nilai resistivitas paling tinggi yaitu pada lapisan bedrock dengan resistivitas 4008,00 Ohm.m dan lapisan paling rendah yaitu pada lapisan tanah penutup dengan resistivitas 68,90 Ohm.m. Menurut nilai Standar Baku Mutu [8], nilai resistivitas yang tidak tercemar yaitu antara (50-333,333) Ohm.m (air tanah). Lapisan tanah penutup, lapisan lempung pasiran, dan lapisan pasir dengan masing-masing nilai resistivitas 68,90 Ohm.m, 119,00 Ohm.m, dan 115,00 Ohm.m diinterprestasikan 
sebagai lapisan yang tidak tercemar oleh polutan air lindi karena nilai resistivitasnya berada antara (50333,333) Ohm.m (air tanah).

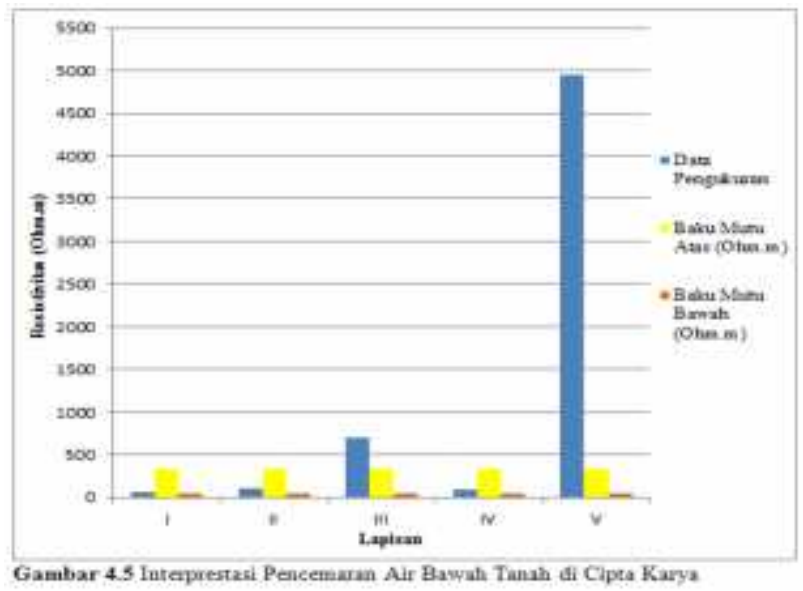

Gambar 5. Interpretasi pencemaran air bawah tanah di Cipta Karya.

Daerah Cipta Karya, berdasarkan diagram diatas menunjukkan nilai resistivitas paling tinggi yaitu pada lapisan bedrock dengan resistivitas 4955,00 Ohm.m dan lapisan paling rendah yaitu pada lapisan tanah penutup dengan resistivitas 57,10 Ohm.m. Menurut nilai Standar Baku Mutu [9], nilai resistivitas yang tidak tercemar yaitu antara (50-333,333) Ohm.m (air tanah). Lapisan tanah penutup, lapisan lempung pasiran, dan lapisan pasir dengan masing-masing nilai resistivitas 57,10 Ohm.m, 98,70 Ohm.m, dan 91,00 Ohm.m diinterprestasikan sebagai lapisan yang tidak tercemar oleh polutan air lindi karena nilai resistivitasnya berada antara (50-333,333) Ohm.m (air tanah).

\section{KESIMPULAN}

Berdasarkan nilai resistivitas yang diperoleh, kedua lintasan tidak tercemar oleh air lindi karena air lindi tidak meresap ke dalam tanah. Hasil pengukuran geolistrik setelah diolah dengan program progress menunjukkan nilai resistivitas sebenarnya yaitu di lintasan titik pertama jalan Cipta Karya (57,10-4955,00) Ohm.m dan di lintasan titik kedua jalan Srikandi $(68,90-4008,00)$ Ohm.m.

\section{REFERENSI}

1. Djajadiningrat, S. T. \& Harsono, H. (1990). Penilaian secara cepat sumbersumber pencemaran air, tanah dan udara. Yogyakarta: Gadjah Mada University press.

2. Soininen, H. (1985). The behavior of the apparent resistivity phase spectrum in the case of two polarizable media. Journal of Geophysics, 50, 810-819.

3 Alile, O. M., Molindo, W. A., \& Nwachokor, M. A. (2007). Evaluation of soilprofile on aquifer layer of three location in edo state. International Journal of Physical Sciences, 2(9), 249253.

4. Derana, T. I. (1981). Perbandingan interpretasi geolistrik, aturan Wenner dan Schlumberger. Skripsi Jurusan Geologi Fakultas Teknik Universitas Gadjah Mada, Jogjakarta.

5. Effendi, H. (2003). Telaah kualitas air. Yogyakarta: Kanisius.

6. Hendrajaya, L. \& Arif. (1990). Geolistrik tahanan jenis. Bandung: Laboratorium Fisika Bumi ITB.

7. Loke, M. H. (1999). Electrical imaging surveys for environmental and engineering studies

8. Sutrisno, C.T \& Suciastuti, E. (1987). Teknologi penyediaan air bersih. PT. Rineka Cipta. Jakarta.

9. Telford, W. M., Geldart, L. P., Sheriff, R. E., \& Keys, D. A. (1990). Applied geophysic. London: Cambridge University Press. 